\title{
Biology, Dispersal and Management of Coffee Berry Disease: A Review
}

\author{
Zenebe Wubshet $^{1} \quad$ Dawit Merga $^{2}$ \\ Ethiopian Institute of Agricultural Research, Jimma Agricultural Research Centre, Plant protection \\ (physiopathology),' Research Section, P.O. Box 192, Jimma, Ethiopia
}

\begin{abstract}
Colletotrichum spp. are the most important plant pathogenic fungi affecting tissues of leaves, flowers, fruit, stems and crown parts of different crops. They are predominantly found in tropical and subtropical rejoins of humid and sub-humid areas. From these, coffee berry disease (CBD) caused by the fungus Colletotrichum kahawae which is one of the predominant challenges in coffee production. Hence, this review is valuable in providing better insights into the extent spread, and biology of CBD pathogen from different findings and helpful for the selection of better management strategies for this disease. The slow growth form of C. kahawae is varied metabolically by its inability to use either citrate or titrate as a sole carbon source, and conidial production, dispersion and germination takes place in the presence of moisture. Also, the conidia from mummified berries and twig barks disseminated by rain splashes are the primary inoculums sources. Also, spore movement is down ward in tree canopies with the guide of water movement. Passive vectors that can carry viable spores like man, insects, vehicles and birds assist long distance movement, and free movement of coffee planting materials from CBD infected origin fasten frequent distribution of the disease. In spite of little attention received at the early stage of its emergence, African coffee growers soon observed a rapid dissemination throughout important Arabica coffee growing areas which causes $75 \%$ losses in Kenya within short time of its appearance. Moreover the impact due to this disease can cause $100 \%$ losses in the area where effective management options like cultural practices, host plant resistance, biological control and chemical control are not applied. So, in order to improve the income gained from coffee sector especially in the areas where it highly produced and offer as essential economic source like Ethiopia needs great emphasis of disease diagnosis as well.
\end{abstract}

Keywords: Coffea arabica, Disease management, Disease symptoms, Epidemiology, Life cycle

DOI: $10.7176 / \mathrm{JBAH} / 10-20-03$

Publication date:October $31^{\text {st }} 2020$

\section{INTRODUCTION}

Coffee is the major sources of currency for different states that produce it and serve as a means of livelihood with a significant economic, social and spiritual impact on many communities with diverse cultural and/or psychological backgrounds (Labouisse et al., 2008; ITC, 2011; Chauhan et al., 2015). It is the world's second most traded commodity next to petroleum and serves as a direct source of income for the growers in different parts of the world (Kiwanian, 2013; FAO, 2015). As well, it is the pillar for Ethiopian economy which contributes about $27 \%$ of external transaction in comes via $>25 \%$ rural and urban employment (ICO, 2018).

Nowadays, coffee is grown in more than 80 countries with $>10$ million hectares of land coverage (Etana, 2018). Ethiopia is the primary center of origin and diversity of Arabica coffee and ranks $1^{\text {st }}$ and $5^{\text {th }}$ in Africa and the world respectively (ICO, 2018). The existence of ideal and diverse agroecologies together with forest, semi forest, garden, and plantations production systems in Ethiopia made coffee to be the top agricultural produce in the country (Workafes and Kasahun, 2000).

However, coffee production has been challenged by several biotic and a biotic factors in several African countries (Rakotoniriana et al., 2013; Cristobel et al., 2017).Coffee berry, coffee wilt and coffee leaf rust diseases triggered by Colletotrichum kahawae, Gibberella xylarioides and Hemileia vastatrix respectively are the major threats of coffee in tropical and subtropical areas. These diseases mainly attack fruits, leaves, stems and roots (Derso and Waller, 2003; Adugna et al., 2009a).

Also, CBD (C. kahawae)(Waller and Bridge, 1993) affects the economic parts of green coffee berries and becomes the leading concern across coffee producing African countries(Van der Vossen et al., 2015; Alemu et al., 2016). The first record of this disease was in Kenya in 1922 which later distributed to Angola, Cameroon, Malawi, Ethiopia, Tanzania and Uganda with in short time (Weir et al., 2012; Alemu, 2013). The losses due to CBD on individual farms vary considerably (up to $100 \%$ ) where no control measures are undertaken in the high rainfall and high altitude areas (Van der Graff, 1981). While, use of cultural practices, biological, chemical control and resistant varieties play a significant role in combating the disease (Adugna et al., 2008).

So, CBD management by reliable methods preferred by farmers that bring tangible change on their economy with increasing productivity as well as effective control of CBD while minimizing production costs and reducing potential consequences on human health and the environment is crucial. Therefore, this review is important to provide key information on the level of distribution, biology and management of the disease from different findings 
and documentations

\section{Ethiopian economy and the coffee sector}

Commercial production of coffee depends on two major species, Coffea arabica and Coffea canephora Pierre which account for $65 \%$ and $35 \%$ of production respectively (Chauhan et al., 2015). Coffee production by exporting countries has been on a gradual increase and is subjugated to the top three producing countries (Brazil, Vietnam and Colombia)by $30 \%, 15 \%$ and $12 \%$ respectively (USDA, 2018). Brazil is the largest Arabica coffee producer from the world, while Vietnam, which is a relatively new candidate and now the world's largest Robusta producer (ICO, 2016).

Ethiopia is the birth place and also major producer and consumer of $C$. arabica, that ranks $1^{\text {st }}$ from Africa $5^{\text {th }}$ in the world (ICO, 2018). From agricultural sectors, coffee industry is the back bone of the country's economy and has contributed vital role in the national income (Grabs, 2017). Coffee in Ethiopia offers $40 \%$ of total export, $10 \%$ of government revenue (Temesgen and Getachew, 2016) and income sources for more than 15 million people (16\% population) whom directly or indirectly engaged in the production, processing and trading (CSA, 2017) The report from CSA in 2017 indicates that coffee is the most essential Ethiopian's green gold; largest export commodity and shares $4.94 \%$ of the area under all crops which delivers significant impact on the source of revenue on people and economic development of the country. It contributes as immeasurable amount of Ethiopian export earnings and plays an important role in social gathering and local consumptions, more than half of the Ethiopian's coffee produce is consumed locally (Tadesse et al., 2014).

\section{Coffee production systems in Ethiopia}

Coffee is largely cultivated in the Southern, South Western and Eastern parts (Amano, 2014). The country has wider ecologies containing indigenous germplasm which offers the greatest opportunity to produce superior $C$. arabica that allowed Ethiopia to be competitive in the world market. About 700,447 ha of the land have been cropped with coffee (CSA, 2017). Kaffa, Illubabor, Jimma, Wollega, Sidamo, Gedeo, Yirgachefe and Hararghe are the topmost coffee growing and producing areas (Chauhan et al., 2015; Garuma et al., 2015). The four most dominant production systems (forest, semi-forest, and garden and plantation coffee) have practiced in Ethiopia (Workafes and Kasahun, 2000) and the contribution of each production system is $10 \%, 35 \%, 50 \%$ and $5 \% \%$ respectively(Petty et al., 2004).

The level of CBD intensity is varying among production systems due to several factors such as human intervention, shade level and crop diversity (Zenebe, 2019). For instance, homogenous coffee cultivation and frequent human interferences (management strategies, cropping type, etc.) which could attribute the increament of disease level are commonly practiced under garden and plantation production systems (Cerda et al., 2017). While, semi forest and forest production systems composed of heterogeneous coffee genotypes, shade levels and low human interference that reduce disease level as well (Bieysse et al., 2009). Bedimo et al. (2008) and Kebati et al. (2016) have reported that shading creates microclimatic conditions that help to delay fruit ripening that leads to a shift in the period of berry susceptibility in relation to high disease pressure. Similarly, Alemu et al. (2016) have reported variation in CBD intensity which was high in the garden production followed by semifrorest and forest production systems conducted in different coffee growing areas of Ethiopia.

\section{Coffee production challenges}

Coffee production is challenged by several biotic and a biotic factors. Due to this factors, its average yield is very low (about $748 \mathrm{~kg} / \mathrm{ha}$ ) in contrast to the achievement in Latin America and Asia. Moreover, the limited use of improved technologies and best cultural practices by producer's as well as environmental change aggravate the occurrence of insect pests, diseases and coffee weeds and discourages coffee production especially in Ethiopia (Adugna et al, 2009b; Teferi and Ayano, 2017). Mainly, coffee berry disease (Colletotrichum kahawae), Coffee wilt disease (Gibberella xylarioides), coffee leaf rust (Hemileia vastatrix) and Coffee thread blight (Corthicium koleroga) which lead to higher losses in coffee yield by attacking the green berries, vascular tissues (Xylem and phloem) and photosynthetic part (the leaf) respectively (Belachew et al., 2016; Teferi and Belachew, 2018). Currently, Alemu et al. (2016), have reported a national average CBD incidence and severity of $52.5 \%$ and $29.9 \%$, respectively.

\section{Coffee berry disease and its distribution}

The main cause of yield loss in Arabica coffee is due to CBD caused by C. kahawae in Africa (Pires et al., 2015). The disease is considered as coffee anthracnose because it causes great economic damage on expanding green coffee berries by encouraging premature fruit drop and/or fruit mummification (Mohammed and Jambo, 2015; Emana, 2015). The disease was first noticed and identified by McDonald in Kenya 1922 and up to 75\% losses were reported soon after first appearance. In spite of little attention received at the first stage of it emergence, African coffee growers soon observed a rapid dissemination of CBD throughout coffee growing areas. Later, it was 
reported in Angola in 1930, Zaire in 1937, Cameroon 1955-1957, Uganda 1959, Tanzania in 1964 and Zimbabwe, Malawi and Zambia 1985 (Weir et al., 2012; Belachew and Teferi, 2015). Five decades later it was reported in Ethiopia in the Sidamo zone then, spread very quickly in all coffee growing areas until 1978 with remarkable losses (Hindorf and Omondi, 2011). The effect is more important at high altitude plantations in tropics (Fino, 2014). Occasionally, it will have occurred in the lower altitude having cold and damp weather conditions similar to climatic conditions in the higher altitudes (Zeru et al., 2009).

Depending on host susceptibility, pathogen aggressiveness and favorable weather conditions, the occurrence and intensity of CBD varies from place to place and season to season (Alemu et al., 2016). Hence, 51 and $81 \%$ at Melko and Wondogent (Ejetta, 1986) respectively, 38.8 and 17.2\% in SNNP in 1994 (Zeru et al., 2012) losses respectively have been reported. Furthermore, the survey conducted in 1997 and 1998 in six major coffee growing zones of Oromiya region revealed 31 and $32 \%$ average CBD severity in the respective years (Jirata and Asefa, 2000 ); in 10 zones and 31 woredas of the SNNP reported 40 and $22.8 \%$ of incidence and severity, respectively (Negash and Abate, 2000).

The impact of CBD is still more prevalent in the African continent, but has not given critical focus as the major problem elsewhere. Since its emergence, it causes severe yield losses and preventing cultivation of Arabica coffee in the highland regions. In African countries that grown C. arabica, crop losses of 20-30\% are common, but can exceed $80 \%$ in extremely wet years if no control measures are applied (Silva, 2010). Prevalence of low temperature with high rainfall for extended period of time favors CBD development and increases disease occurrence that can results to rots and fruit falling with post-harvest losses ranging from 40 to $80 \%$ (Hindorf and Omondi, 2011).

Free movement of coffee planting materials from CBD infected areas can fasten frequent distribution of the disease (Zeru, 2006). Alemu et al. (2016) reported that all coffee producing Ethiopian coffee ecosystems are suffered with severe impact of CBD more importantly in Borena (10-80\%), Gedio and Hararghe (40-100\%), Illubabor (10-90\%) Jimma and Sidama (30-90\%) and West Wollega (30-80\%) of CBD incidence in each assessed zones during 2014 cropping seasons. CBD results 24 to $30 \%$ national average losses on the susceptible landraces when environmental conditions favored disease development, the loss due to CBD may reach 100\% (Adugna et al., 2009a).

\section{Pathogen (C. kahawae) Taxonomy}

The former taxonomic description and position of $C$. kahawae was subject to confusion from the range of Colletotrichum spp. which are isolated from coffee plants, four groups (C. coffeanum mycelia, $C$. coffeanum acervuli. coffeanum pink and coffee berry disease (CBD) strains) are described initially based on their morphological traits (Gibbs, 1969). From these, the $4^{\text {th }}$ group was the only species which able to infected the green berries. C. gloesporioides and C. acutatum are the former groups which are non-pathogenic for green coffee berries (Hindorf, 1970). However, C. coffeanum was described in 1901 in Brazil from diseased coffee berries (Hyd et al., 2009). Gichuru (2007) and Prihastuti et al. (2009) found that C. gloesporioides occurred as saprophyte (weak pathogen) synonym with CBD pathogen which is more aggressive on ripe coffee berries and coffee tissues with the symptoms of whitish to dark grey discoloration. The causative agent of CBD (C. kahawae) was first identified by Waller and Bridge in 1993 and it is also a distinct species based on morphological, cultural and biochemical character (Batista et al., 2017). Currently, the fungus is under Kingdom: Fungi, Phylum: Ascomycota, Class: coelomocytes, Order: Melanconiales, Family: melanconiaceous, Genus: Colletotrichum m, Species: kahawae (Owaka, 2011).

\section{Biology, Epidemiology and Disease symptoms}

Plant infecting fungi comprises diverse groups of organisms with different life cycles and methods by which they infect and colonize their hosts (Silva et al., 2017). The unstable groups of fungi can use different tissues of the hosts as alternate habitat, and it makes difficult in pathogen identification even if distinction at the sub specific level is provided (Batista et al., 2017). Pathogen diversity can be limited by lack of perfect state which promotes sexual recombination (Omondi, 1998). So, understanding the complex life style patterns of Colletotrichum spp. (Fig.1) and the dynamic state of their host relationship has important implication for management.

The life style of the pathogen can be distinguished metabolically by its inability to use either citrate or titrate as a sole carbon source (Loureiro et al., 2012). The pathogenesis including conidial production, dispersion, and germination is takes place in the presence of rain /water. Asexual spore (conidia) from mummified berries and twig barks disseminated by rain splash are the primary inoculums sources (Griffith et al., 1991; Waller and Bridge, 1993). The spore movement is down ward in tree canopies with the guide of water (moisture) movement whereas long distance movement is via passive vectors like man, insects, vehicles and birds which can carry viable spores or via the movement of infected plant materials (Biratu, 1995). This is the reason why coffee CBD spores on the coffee crowns are laterally dispersed between trees and branches by wind slashing. With this regard, downward movement is considered the primary inoculum movement (Silva et al., 2006). 


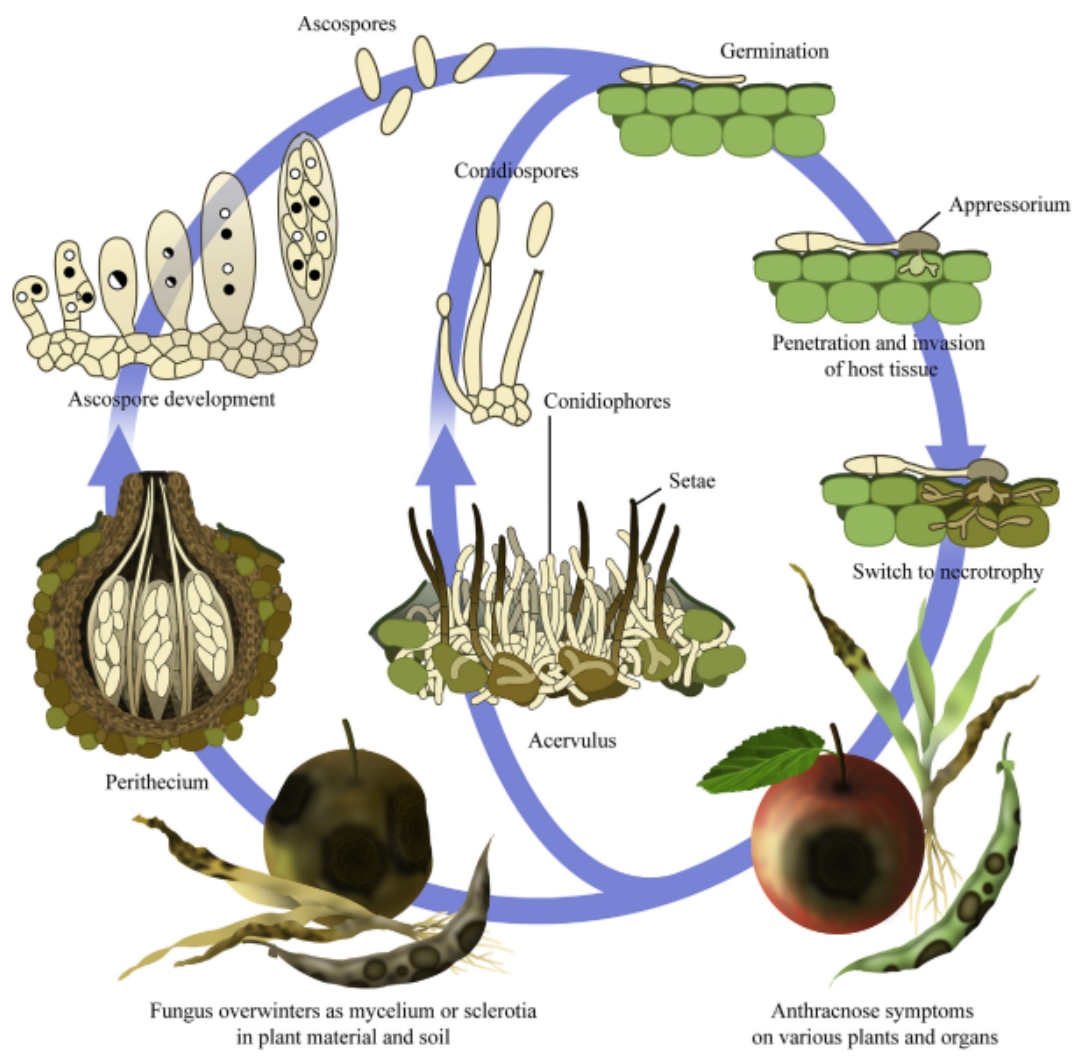

Figure1. General life cycle of Colletotrichum species (Silva et al., 2017)

In the infection process, $C$. kahawae uses hemibiotrophic strategy that includes post penetrative asymptomatic bio trophic phase (attacks the host cell without killing them) followed by destructive necrotrophic phases (involves in the increament of wall degrading enzyme that encourage pathogenicity which culminate the appearance of disease symptoms and fungus reproduction (Loureiro et al., 2012). Tissue colonization is associated with sever cell wall alterations and death of the host protoplast (MouneBedimo et al, 2010). Infection starts with conidial germination (asexual spore). After contact with the host plant tissue, follows germ tube elongation in the apical selection and differentiates in to melanized apresorium which functions as plant cell cuticle penetration (Fig. 2) directly via turgor pressure (mechanical pressure), secretion of cutin degrading enzymes or the combination of the two processes (Silva et al., 2006; MouneBedimo et al., 2010).

The first disease symptom is dark brown slightly sunken spots in favorable situations. The spots enlarge to cover the whole berries and will form visible masses of conidia with black and shriveled lesions on the beans, whereas, infection on ripe berries will be seen as dark sunken patches that spread rapidly through whole berries coverage. Under favorable conditions, the pathogen rapidly sporulates by forming mass of conidia and enters inside the berries via penetration and infection takes place in expanding green berries, leading to premature dropping and mummification of berries (Waller et al., 2007).

Based on resistant or susceptibility response of coffee genotypes, two types of symptoms (scab lesions and active lesions) can be occurred. Scab lesions are plants resistance response that restricts fungal development allows only small black spots formation. But, the deeper layers of the fruit are not invaded that appears as stationary lesion not affecting the normal development of the green berry. However, in the susceptible plants active lesion development is observed starting as little black spots; in the presence of good conditions it can form dark, sunken, active lesions that rapidly expand and destroy the entire fruits (Fino, 2014; Diniz, 2018) 


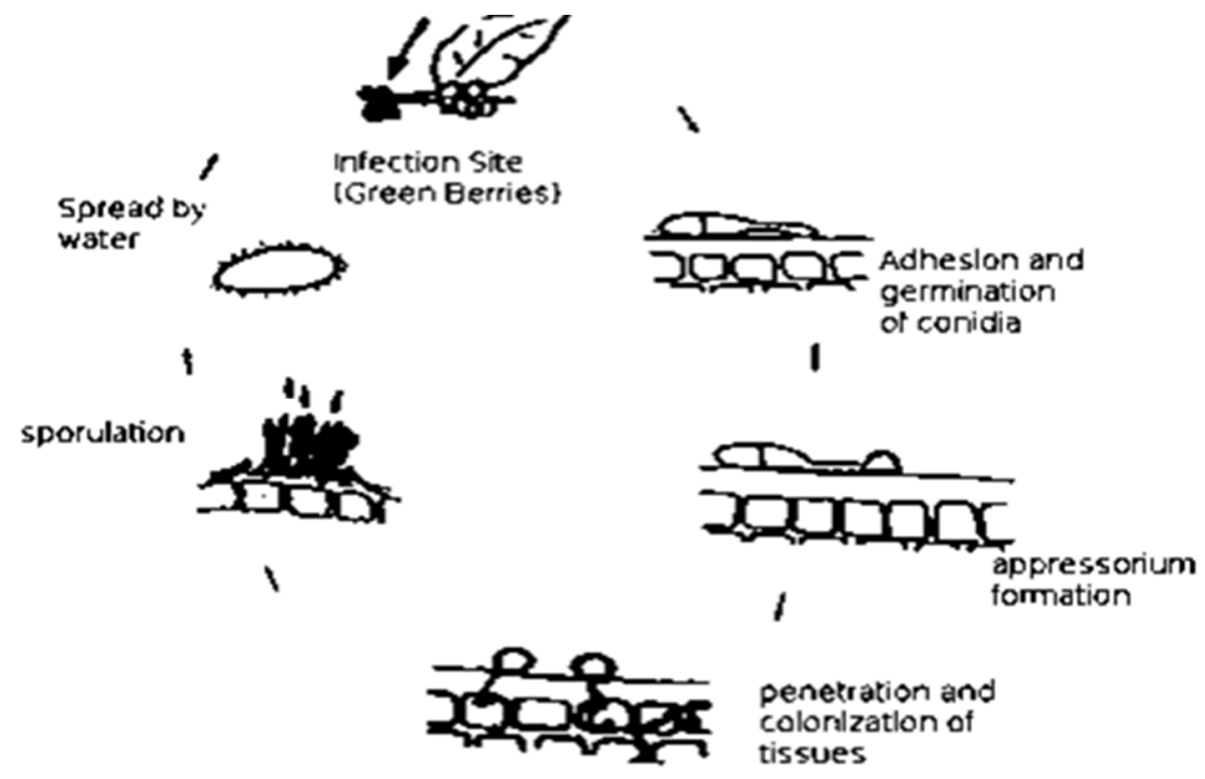

Figure 2. The systemic infection process of Colletotrichum kahawae (Silva, 2010)

\section{Characteristics and variability in $C$. kahawae isolates in various collections}

McDonald had described the first cultural characteristics of $C$. kahawae in 1926. The main distinguishing characteristics of the pathogen include slow growing, cottony and dark grey to greenish mycelium mainly in the young culture. These features are become variable in old cultures (Waller et al., 1993; Omondi, 1998). This common cultural characteristic used as distinct features from other groups of pathogens linked with ripening coffee berries, branches and leaf symptoms. Gibbs (1969) described four main strains of Colletotrichum species collected from coffee with the base of their colony characters and able to separate between the saprophytic strains (mycelia with and without acervuli and pinkish form) in the conidia of C. kahawae borne directly on the hyphae (Gibbs, 1969). The detailed morphological study of Colletotrichum spp. collected from different ecosystem was made by Hindorf in 1970 in Kenya.

Moreover, CBD pathogen has distinctive features which enables it to occupy a unique ecological niche and separates it on a functional basis from all other Colletotrichum species. One is its pathogenicity towards developing green coffee berries (attached and detached berries) and seedling hypocotyls. In places where C. arabica is grown most extensively in the highlands, the pathogen $C$. kahawae did reach the wild population in which much of it was susceptible to the disease (Batista et al., 2017).

Variation between $C$. kahawae isolate collections can be existed due to aggressiveness and cultural characteristics like sporulation, conidial size and shape, appearance on culture, growth rate of the isolates on different media (Rodrigues et al., 1991). These morphological criteria are used as accurate classification of Colletotrichum spp. that invading coffee genotypes (Omondi, 1998). They are varying in growth rate and conidial length when they grow in different media. Zeru (2006) reported $4.4 \mathrm{~mm} / \mathrm{d}$ of average growth rate, 14.1 and $4.2 \mu \mathrm{m}$ of the conidial length and width respectively when it cultured in different media. The conidia of $C$. kahawae can be distributed by water splashes because it requires the presence of water or $100 \%$ relative humidity and optimum temperature of about $22{ }^{\circ} \mathrm{C}$ for germination. Additionally, correct identification and characterization of disease causing fungal pathogens need to detect the morphological features such as mycelial color, growth rate, conidial production in the invitro conditions and testing the pathogenicity on the berries or hypocotyls (Hindorf et al., 1997).

Aggressiveness can be considered as quantitative measure of the level of disease reached over time. Most of the aggressive pathogen reached at the specific disease level faster than the less aggressive and can be measured by spore production, infection size, latent periods and its severity on the host (Luzolo et al., 2010; Pires et al., 2016). Factors like geographical origins have attributed for aggressiveness of $C$. kahawae populations. But isolates collected from different geographical locations may showed similar reaction but varies in their aggressiveness on the inoculated genotypes (Fredrik et al., 2015). Besides, variation in sporulation and rate of growth of the pathogen can lead to variation in aggressiveness of $C$. kahawae isolates (Kilambo, 2008).

Beynon et al. (1995) reported that C. Kahawae strains collected from Cameroon, Zimbabwe, Kenya, Burundi, Tanzania and Ethiopia and the strains from Malawi were the most virulence and cause severe disease in comparison to others. Furthermore, variation within pathogen population can be appeared due to migration or gene flow followed by mutation or recombination (Margaret, 2011). Virulence tests of $C$. kahawae isolates used to detect the exhibited variation among aggressiveness isolates (Fredrick et al., 2015). Also, susceptible genotypes are clear indicators of aggressiveness difference among pathogen isolates (Castiblanco et al., 2018). 


\section{Host resitance mechanisms}

Defense responses of the genotypes are considered to be dependent on the pathogen lifestyle and the genetic constituent of the host (Adolf and Ercolano, 2015; Ma and Ma, 2016). Pre-formed and induced mechanisms are among the most mechanisms in the host response for pathogen. In coffee resistance for CBD can be characterized by partial fungal development allied by means of host resistance like hypersensitive reaction (HR) which is the rapid localized cell death, formation of structural barriers and antifungal compounds like accumulation of callose, lignin-like and phenolic compounds (Silva et al., 2006; Loureiro et al., 2012). Some of these mechanisms are likely to be pathogen nonspecific and could induced by mechanical injury. It may be possible to develop some of the observed biochemical and structural changes into methods of screening for CBD resistance. Traits of interest in permanent crops like disease resistance can be observed and screened more importantly at late stages of development and require assessment over a number of years at different location. Besides, the susceptibility of green berries for C. kahawae is varied with the development stages (Vieira et al., 2018); hence, evaluation at green berries expanding stage is better than at green berries mature.

\section{Research achievement in resistance development for CBD in Ethiopia}

In Ethiopia, CBD resistance selection program was designed soon after the outbreak of CBD in 1971. High genetic variability among coffee genotypes were observed through massive selection programs on indigenous resistance coffee populations basically with four critical steps, selection and testing of coffee mother trees without or with a very low CBD infection via visual assessment and berry count in the natural infested fields and attached or detached berry tests, screening of their progeny and multiplication in large blocks (Ejetta, 1986). Robinson (1976) found that resistant trees occurred at frequencies of $0.1 \%$ to $1 \%$ and one tree in every 10,000 possessed both resistance and high yield and quality. Genetic resistance appears to be partial in $C$. arabica and complete in $C$. canephora (Van der Vossen et al., 2015).

Breeding strategies for resistance selection provides sustainable and extended regulation of the disease in different coffee producing countries (Alemu et al., 2018). However, the application methods vary from country to country depending on the genetic variability, ecological conditions and production problems (Belachew, 2001). As Ethiopia is the center of origin and diversity of Arabica coffee, initial emphasis of breeding was agroechological based resistant development by subsequent evaluation of mother trees at their place of origin and the progenies at laboratory and experimental plots. Furthermore, pure line selection and intra specific hybridization methods are used commonly in Ethiopia till now (Benti, 2017).

During the past four decades, genetic based resistant variety development and identification research works have conducted via great struggles. For $1^{\text {st }}$ time, from 218 promising selections 13 CBD resistant varieties were identified and released within five years (1972-1978) in the country (Van der Graff, 1981). These released varieties have played significant role in the coffee industry and the varieties are still under production at diverse agroecologies (Belachew, 2001; Benti, 2017). From long time effort, about 31 pure lines of CBD resistant cultivars had been released and are in production in coffee growing areas of the country today (Belachew et al., 2015; Benti, 2017).

\section{Disease (CBD) management approaches}

It is clear that $\mathrm{CBD}$ is a great threat in the coffee ecology. So, in order to improve the income gained from it, there must be a need to manage using different options that minimize the risk (Van der Vossen et al., 2015; Alemu et al., 2016). Some of the approaches are listed below

Cultural practices: Cultural practices are likely to reduce losses due to $\mathrm{CBD}$. There are some reports that promote good aeration and rapid drying of the canopy, such as adequate pruning and wide spacing can reduce disease incidence. Likely, pruning is an agricultural operation commonly practiced in tree crops. These practices used as to correct the tree stand and assimilating scheme, stimulate new reproductive organs and controlling numerous diseases. On the other hand, pruning during the vegetative growth period can leads to the effective means of removing diseased branches, berries, susceptible and old trees can reduce the initial inoculums sources through maintenance pruning and mummified berry removal (Holb, 2005; Bedimo et al., 2007). Furthermore, use of irrigation in coffee farm can shift the susceptible stage of berry development and attributed for the reduction of disease incidence (Gidisa, 2016).

As coffee trees are shade lovers, proper shading of coffee trees considerably reduced CBD development. Because, shade minimizes light intensity and plays crucial usage for modification of the micro environmental conditions (reduce temperature fluctuations, air movements and could limit the rain intensity) and work as a barrier, limits the dispersal and development of the pathogen (Jha et al., 2014). According to Bedimo et al. (2008) findings, shade can reduce more than $30 \%$ CBD incidence in coffee plantation.

Host plant resistance: There is a strong agreement that host resistance (HR) is the most preferred, appropriate, cost effective, biologically save and sustainable way of controlling diseases and pests (Margaret, 2011). But, growing resistance varieties need strong work in identifying the sources of genetic resistance form existed coffee 
germplasm. Resistance to CBD in Coffea arabica most probably is horizontal/ quantitative in nature and controlled by three to five recessive genes (Van der Graff, 1984).

Likewise, resistant variety development in Ethiopia started after the outbreak of CBD in 1971 and is still in use as the best disease management option. Finding of stable (durable) resistance could guarantee sustainable production for the growers. Availability of varieties with durable resistance to CBD could provide economically and environmentally attractive and alternative for costly fungicide spraying (Van der Vossen and Walyaro. 2009). It also avoids residual effects of fungicides to the sprayers and saves the time spent for spraying. In particular, it is a useful resource for poor smallholder farmers of main coffee producers in Ethiopia. Development of resistant varieties increases the productivity and production of coffee, also saves the nation a considerable amount of foreign exchange that spent for purchasing fungicides (Habte, 2005).

The exhaustive testing of materials for CBD resistance selection from the mother trees and in their progenies in laboratory where the disease epidemic is not only severe but also regularly present is very vital (Derso et al., 2000). In African countries such as Tanzania, Cameroon, Kenya, Ethiopia HR approach is in practical till now (Bedimo et al., 2008). Masaba and Van der Vossen (1982) reported that formation of cork barriers as the mechanism of resistance to CBD based on the stability against changes in pathogen populations. In Ethiopia, Jimma Agricultural Research Center has developed 42 coffee varieties characterized by high yielder, with the better quality for different Ethiopian agroecollogies (Dawit and Daba, 2020; under publication)). Among these varieties, 31 of them are CBD resistant selections.

Biological control: implies the involvement and use of antagonistic microorganisms such as fungi and bacteria having specialized and modified genes or gene products to attack/control/ plant pathogens causing diseases. Plant pathogenic pathogens (the pathogens that cause diseases on corps) have several influences in the crop ecology and will cause total crop loss

Biological control of plant pathogens is the primary factors in disease suppression, but the possibility in the sustainable context becomes the major contradiction issues among researchers (Weller et al., 2002). Bio agents in the world provides unlimited source to control pathosystem. They are also more robust than disease control with synthetic chemicals. The complexity of the organism interactions, the involvement of numerous mechanisms of disease suppression by a single microorganisms and the addictiveness of most bio control agents to the environment in all contribute to the belief that as more durable than synthetic chemicals (Serani et al., 2007; Rodriguez, 2016).

Soil microbes have hostile behaviors towards pathogens. Like Bacillus/Paenibacillus and Pseudomonas spp. which used as bio agents that receive much attention and tested on a varied variety of plant species for their ability to control diseases. The worldwide interest in these groups of bacteria was sparked by studies initiated for sustainable production systems. They are the main candidates for the biological control of diseases induced by fungal pathogens and they have been applied successfully to suppress Fusarium wilts of various plant species (Mulatu, 2012; Rodriguez, 2016).

For instance, Asfaw et al. (2018) collected 348 specimens (from leafs, twigs and berries) from Oromiya and SNNPs areas to test as the bio-agents for CBD management options under invitro conditions. After stepwise testing of these isolates, they have reported 33 bio agents (10 anti-biotic bacteria, 10 antibiotic yeast, 10 antibiotic filamentous fungi and 3 lytic bacteria) as effective bio agents under invitro conditions. This directs that, if we give great concern for biocontrol agents for CBD management we will get effective result likewise under in vivo conditions especially in our country Ethiopia.

Induction of systemic resistance: this linked with gene induction, creation of resitance means and the fabrication of broad array protection composites which result in metabolic and structural changes inside plants against pathogens (Sillero. 2012). This is an extensive happening that has been intensively considered by means of value to the fundamental indication path for potential use in plant protection (Saikia et al., 2003). Different authors reported that, application of plant defense inducing chemicals are used to triggering host resistance against pathogens (Ata et al., 2008; Aleandri et al., 2010). These plant inducing chemicals are also important in triggering resistance in $C$. arabica against $\mathrm{CBD}$.

Recently in Ethiopia, Alemu et al. (2018) conducted an experiment on the effects of inducing chemicals (Jasmonic acid, Monopotassium phosphate, Di potassium phosphate and Salicylic acid) against the development of CBD via artificially inoculated coffee hypocotyls and have reported that all the tested chemicals are successful in the decline of CBD index. The experiment have the indication that the application of these multifaceted chemicals in different concentration can give the best result as the best alternative potential tools for future CBD management also at in vivo conditions.

Chemical control: The use of chemicals are the primary management tactic which can give immediate control of anthracnose diseases like CBD, but cultivation methods and yield levels can limit its application. It is often difficult to sprays trees which are unpruned and irregularly spaced. Many areas are inaccessible during the rainy season. Therefore, areas which have above average yield prospect, suffer due to severe losses and the disease remains unchecked. The proper uses of chemicals are heavily subsidized to make treatment attractive in the suitable areas 
(Vander Graff, 1981).

Yet, the high cost of fungicides (45\% of production cost including the labors), appearance of resistant pathogen biotype and other social and health related problems in the environment of conventional agriculture will delivers immense topics when thinking to increase the interest of sustainable agriculture and biodiversity conservation (Swami and Alane, 2013). Several farmers are challenging with low coffee expenditure and growing interest in purely grown coffee across the globe. So, the inadequacy of such elaborate control measures, losses of the potential crop becoming high (50\%) under unfavorable weather condition (Waller, 2007). Moreover, it is costly in a context of smallholdings struggling to cope with an unprecedented economic crisis (Alwora and Gichuru, 2014; Etana, 2018). Different copper-based fungicides, organic fungicides, as well as mixtures of the two are recommended to control CBD. These problems make it essential to look for alternative strategies that can ensure competitive and save habits of coffee production systems (Abera et al., 2011; Ngouegn et al., 2017).

\section{Summary and Conclusion}

Coffee has significant economic, social and spiritual impact on many communities that favors diverse cultural and/or psychological backgrounds. Yet, coffee producers have been challenged with various biotic and a biotic factors. Coffee berry disease (Colletotrichum kahawae), coffee wilt disease (Gibberella xylarioides) and coffee leaf rust (Hemileia vastatrix) attacking fruits, leaves, stems and roots, respectively are the leading influences especially in tropical and subtropical areas. Essentially, CBD caused by C. kahawae which affect the green berries is the great threat of the coffee sector/ industry/ today.

Correspondingly, in African continent that produce coffee as the main sources of hard currency as Ethiopia, the primary cause of yield loss in Arabica coffee is due to CBD induced by C. kahawae. This pathogen causes great economic damage on expanding green coffee berries by encouraging premature fruit drop and/or fruit mummification and considered as coffee anthracnose. Due to limited emphasis given to this disease it has distributed in many countries within a short time and has suffered coffee producers. Different research report revealed that $\mathrm{CBD}$ can cause more than $80 \%$ when no control measures are undertaken. With this regards, application of appropriate management options like host resitance, cultural practices, and biological control agents can reduce the risk of production. Even if some research technologies are available, they are shelfed due to weak extension system that links the farmers with technologies especially in Ethiopia which fasten disease spreading in different coffee ecology easily.

In general, knowledge of life styles of the pathogen (C. kahawae), use improved technologies like resistant varieties, biocontrol agents, integrated management options, cultural practices and chemicals as last option and strong extension systems can be mitigate the risk of the disease across the coffee production areas. With this respects, study on the detailed knowledge on the biology, dissemination and the nature of interaction (host pathogen interaction) of CBD pathogen should be future research focus. Moreover, there are many fungal and bacterial bio agents that are not given great intention as CBD management options. Yet, their effectiveness needs great efforts of the experts and integration experimental works of disciplines.

\section{References}

Abera, A., Lemessa, F. and Muleta, D., 2011. Antifungal activity of some medicinal plants against coffee berry disease caused by Colletotrichum kahawae. International Journal of Agricultural Research, 6: 268-279.

Adugna, A., Chemeda J., Arega Z., Tesfaye. 2009a. Advances in coffee diseases research in Ethiopia. Vol. ii proceeding of the 14th annual conference of the plant protection society of Ethiopia, 540: 275-303.

Adugna, A., Million, A., Hindorf, H., Arega, Z., Teferi, D. and Jefuka, C., 2009b. Coffee wilt disease in Ethiopia. Pp. $50-68$.

Adugna, G. and Jefuka C., 2008. Resistance levels of Arabica coffee cultivars to coffee berry disease, coffee wilt and leaf rust diseases in Ethiopia. Proceedings of the $12^{\text {th }}$ Crop Science Society of Ethiopia (CSSE), $22-24$ May 2006, Addis Ababa, Ethiopia, pp. 92 - 103.

Adugna, G., Teferi D, Jafuka C, Tesfaye S, Zeru A. 2008. Research findings in coffee wilt disease. In: Adugna G, Bellachew B, Shimbir T, Taye E, Kufa T, editors. Coffee diversity and knowledge. Proceeding of a national workshop four decades of coffee research and development in Ethiopia, p. 205-260.

Aleandri, M.P., Reda, R., Tagliavento, V., Magro, P. and Chilosi, G., 2010. Effect of chemical resistance inducers on the control of Monosporascus root rot and vine decline of melon. Mediterranean Phytopathology, 49: 1826.

Alemu, F., 2013. Assessment of the current status of coffee diseases at Gedeo and Sidama zone, Ethiopia. International Journal of advanced research, 1: 192-202.

Alemu, K., Adugna, G., Lemessa, F. and Muleta, D., 2016. Current status of coffee berry disease (Colletotrichum kahawae Waller \& Bridge) in Ethiopia. Archives of Phytopathology and Plant Protection, 49: 421-433.

Alemu, K., Adugna, G., Lemessa, F. and Muleta, D., 2018. Induction of systemic resistance in Arabica coffee (Coffea arabica L.) against coffee berry disease (Colletotrichum kahawae Waller and Bridge) mediated 
through plant defense activator. International Journal of Pest Management, pp.1-11.

Alwora, G.O. and Gichuru, E.K., 2014. Advances in the management of coffee berry disease and coffee leaf rust in Kenya. Journal of Renewable Agriculture, 47:777-780

Andolfo, G. and Ercolano, M.R., 2015. Plant innate immunity multi component model. Frontiers in plant science, 6: 987.

Asfaw, K., Husein T., Ayalew A., Dejene M. and Sahile S., 2018. In vitro Screening and characterizing the most promising antagonistic microorganism as Biocontrol Agent(s) against Colletotrichum kahawae. European Journal of Experimental Biology, 8: 1-13

Ata, A.A., El-Samman, M.G., Moursy, M.A. and Mostafa, M.H., 2008. Inducing resistance against rust disease of sugar beet by certain chemical compounds. Egyptian Journal of Phytopathology, 36:113-132.

Batista, D., Silva, D.N., Vieira, A., Cabral, A., Pires, A.S., Loureiro, A.P., Azinheira, H., Talhinhas, P. and Silva, M.D.C., 2017. Legitimacy and implications of reducing Colletotrichum kahawae to subspecies in plant pathology. Frontiers in plant science, 7: 2051.

Bedimo, J.A.M., Bieysse, D., Njiayouom, I., Deumeni, J.P., Cilas, C. and Nottéghem, J.L., 2007. Effect of cultural practices on the development of arabica coffee berry disease, caused by Colletotrichum kahawae. European Journal of Plant Pathology, 119: 391.

Bedimo, J.M., Njiayouom, I., Bieysse, D., Nkeng, M.N., Cilas, C. and Nottéghem, J.L., 2008. Effect of shade on Arabica coffee berry disease development: toward an agro forestry system to reduce disease impact. Phytopathology, 98: 1320-1325.

Belachew, B., 2001. Arabica coffee breeding for yield and resistance to coffee berry disease (Colletotrichum kahawae sp. Nov). Dissertation, Imperial College at Wye, University of London, pp. 232

Belachew, K. and Teferi D., 2015. Climatic variables and impact of coffee berry diseases (Colletotrichum Kahawae) in Ethiopian coffee production, 5: 55-64

Belachew, k., Demelash T., Niguse H., and Sisay T., 2016. The Statue and Management of coffee wilt disease (Gibberella xylarioides) in Ethiopian coffee production, 6: 16-25.

Belachew, K., Teferi, D. and Gidisa, G., 2015. Screening of Some Coffea arabica genotypes against coffee wilt diseases (Gibberella xylarioides Heim and Saccus) at Jimma, Southwest Ethiopia. International Journal of Sustainable Agricultural Research, 2: 66-76.

Benti, T., 2017. Progress in Arabica coffee breeding in Ethiopia: Achievements, challenges and Prospects. Ethiopian Institute of Agricultural Research (EIAR), Jima Agricultural Research Center (JARC), Jimma, Ethiopia, 33:15-25.

Beynon, S.M., Coddington, A., Lewis, B.G. and Varzea, V., 1995. Genetic variation in the coffee berry disease pathogen, Colletotrichum kahawae. Physiological and molecular plant pathology, 46(6), pp.457-470.

Bieysse, D., Cilas, C., Bedimo, M., Aubert, J., Musoli, C.P. and Avelino, J., 2008. Coffee disease risk analysis: how epidemiology knowledge could help in assessing and preventing disease invasion. ASIC.

Castiblanco, V., Castillo, H.E. and Miedaner, T., 2018. Candidate Genes for aggressiveness in a Natural Fusarium culmorum Population Greatly Differ between Wheat and Rye Head Blight. Journal of Fungi, 4: 14

Cerda, R., Allinne, C., Gary, C., Tixier, P., Harvey, C.A., Krolczyk, L., Mathiot, C., Clément, E., Aubertot, J.N. and Avelino, J., 2017. Effects of shade, altitude and management on multiple ecosystem services in coffee agro ecosystems. European Journal of Agronomy, 82, pp.308-319.

CSA (Central Statistical Agency), 2017. Area and production of major crops in the Federal democratic republic of Ethiopia central statistical agency agricultural sample survey, 1: 1-117.

Derso, E. and Waller, J.M., 2003. Variation among Colletotrichum isolates from diseased coffee berries in Ethiopia. Crop protection, 22:561-565.

Derso, E., 1997.Coffee diseases and their significance in Ethiopia. ASIC, 17:723-726.

Derso, E., Girma A. and Gebrezgi H., 2000. Control of coffee berry disease by fungicide in Ethiopia. In processing of the workshop on control coffee berry disease in Ethiopia, pp. 35-47.

Diniz, I.I.P.D.S., 2018. An innovative integrated approach to characterize coffee resistance mechanisms to Colletotrichum kahawae, pp. 1-84.

Ejetta, M., 1986. A review of coffee diseases and their control in Ethiopia. In Tsedeke Abate (ed.) Proceedings of the first Ethiopian crop protection symposium, 4-7 February 1985, Addis Ababa, Ethiopia, Pp. 179-195.

Emana, B.T., 2015. Distribution assessment and pathogenicity test of coffee berry disease (Colletotrichum kahawae) in Hararghe, Ethiopia, 2: 038-042

Etana, M.B., 2018. Review on the Management of Coffee Berry Disease (Colletotrichum kahawae) in Ethiopia. Journal of Food Science and Quality Management, 76:73-76

FAO (Food and Agricultural Organization), 2015. Food and Agricultural Organization of the United Nation statistical pocketbook of coffee, pp. 1-194.

Fino, J.R.V., 2014. Analysis of RNA-seq data from the interaction of Coffea spp. Colletotrichum kahawae (Doctoral dissertation), pp. 1-74. 
Fredrick, M. N., Owaka M., Chrispine O., Elijah K., 2015. Pathogenicity of Colletotrichum kahawae in Kenya. International Journal of Science, 6: 2319-7064.

Garuma, H., Berecha, G. and Abedeta, C., 2015. Influence of Coffee Production Systems on the Occurrence of Coffee Beans Abnormality: Implication on Coffee Quality. Asian Journal of Plant Sciences, 14: 40-44.

Gibbs, J.N., 1969. Inoculums sources for coffee berry disease. Annals of Applied Biology, 64: 515-522.

Gichimu, B.M., Gichuru, E.K., Mamati, G.E. and Nyende, A.B., 2014. Occurrence of Ck-1 gene conferring resistance to coffee berry disease in Coffea arabica cv.55 Ruiru 11 and its parental genotypes. Journal of Agricultural and Crop Research, 2:51-61.

Gichuru, E.K., 2007. Sensitive response and resistance to berry disease (Colletotrichum kahawae) of two coffee varieties (Coffea arabica and C. canephora): histological comparisons of interactions. Agronomies Africanize, 19: 233-240.

Gidisa, G., 2016. A review on the status of coffee berry disease (Colletotrichum kahawae) in Ethiopia, .6:140-151.

Grabs, J., 2017. "The rise of buyer-driven sustainability governance: Emerging trends in the global coffee sector. ZenTra Working Paper in Transnational Studies No. 73 / 2017. Available at SSRN: https://ssrn.com.

Griffiths, E., Gibbs, J.N. and Waller, J.M., 1991. Control of coffee berry disease. Annals of Applied Biology, 67: 45-74.

Habte E., 2005. Evaluation of Wollega coffee germplasm for yield, yield component and resistant to coffee berry disease at early bearing stage. MSc thesis the University of Alemaya, pp. 1-58.

Hindorf, H. and Omondi, C.O., 2011. A review of three major fungal diseases of Coffea arabica L. in the rainforests of Ethiopia and progress in breeding for resistance in Kenya. Journal of advanced research, 2: 109-120.

Hindorf, H., 1970. Colletotrichum spp. isolated from Coffea arabica L. in Kenya for phytoplankton Journal of Plant Diseases and Protection, pp. 328-331.

Hindorf, H., Biratu, T. and Omondi, C.O., 1997. Correct identification of the pathogen/Colletotrichum kahawae/causing coffee berry disease (CBD) in Kenya Nairobi, 17: 599-603.

Holb, I.J., 2005. Effect of pruning on apple scab in organic apple production. Plant Disease, 89: 611-618.

Hyde, K.D., Cai, L., Cannon, P.F., Crouch, J.A., Crous, P.W., Dam, U., Goodwin, P.H., Chen, H., Johnston, P.R., Jones, E.B.G. and 'Liu, Z.Y., 2009. Colletotrichum names in current use. Fungal Diversity, 39:147-183.

ICO (International Coffee Organization), 2016. International coffee organization associated meetings for sustainable credit guarantee scheme and promotes scaling up of enhanced processing practices in Ethiopia and Rwanda (CFC/ICO/48), United Kingdom, pp. 1-46

ICO (International coffee organization), 2018. Coffee market report in the international trade, challenges and opportunities facing the sector, pp.1-8

International Trade Center (ITC), 2011.The Coffee Exporter's Guide, Third ed., Geneva, (Doctoral dissertation), pp. 267.

Jha, S., Bacon, C.M., Philpot, S.M., Ernesto Mendez, V., Läderach, P. and Rice, R.A., 2014.Shade coffee: update on a disappearing refuge for biodiversity. Bioscience, 64: 416-428.

Jirata and Assefa, 2000. Status of coffee berry disease in Oromiya region. In: proceedings of the workshop on control of coffee berry Disease (CBD) in Ethiopia, August 13-15 1999, Addis Ababa, Ethiopia, pp. 9-17

Kebati, R.K., Nyangeri, J., Omondi, C.O. and Kubochi, J.M., 2016. Effect of artificial shading on severity of coffee berry disease in Kiambu County, Kenya. Annual Research \& Review in Biology, 9: 1-11.

Kilambo, D.L., 2008. Virulence of Colletotrichum kahawae strains and their effect on resistant Arabica coffee varieties in Tanzania (Doctoral dissertation, Sokoine University of Agriculture), pp, 1-79.

Kiwanian, R., 2013. Essays on global coffee supply chains: improving small-scale producers' income (Doctoral dissertation, Rutgers University-Graduate School-Newark), pp. 1-157.

Labouisse, J.P., Bellachew, B., Kotecha, S. and Bertrand, B., 2008. Current status of coffee (Coffea arabica L.) genetic resources in Ethiopia: implications for conservation. Genetic Resources and Crop Evolution, 55: 1079.

Loureiro, A., Nicole, M.R., Varzea, V., Moncada, P., Bertrand, B. and Silva, M.C., 2012. Coffee resistance to Colletotrichum kahawae is associated with lignification's, accumulation of phenols and cell death at infection sites. Physiological and molecular plant pathology, 77:23-32.

Luzolo M, Talhinhas P, Várzea V, Neves-Martins J, 2010. Characterization of Colletotrichum Kahawae isolates causing coffee berry disease in Angola. Journal of Phytopathology, 158:310-313.

Ma K-W, Ma W., 2016. Phytohormone pathways as targets of pathogens to facilitate infection. Plant Molecular Biology, 91: 713-725.

Manuel, L., Talhinhas, P., Várzea, V. and Neves-Martins, J., 2010. Characterization of Colletotrichum kahawae isolates causing coffee berry disease in Angola. Journal of phytopathology, 158: 310-313.

Margaret, O., 2011. Characterization of the genetic diversity and pathogenicity of Colletotrichum kahawae using random amplified polymorphic DNA (RAPD) analysis (Doctoral dissertation, School of Pure and Applied Sciences, Kenyatta University), pp.1-56.

Masaba, D.M. and Vander Vossen, H.A.H., 1982. Evidence of cork barrier formation as a resistance mechanism 
to berry disease (Colletotrichum coffeanum) in Arabica coffee. European Journal of Plant Pathology, 88: 1932.

Mohammed, A. and Jambo, A., 2015. Importance and characterization of coffee berry disease (Colletotrichum kahawae) in Borena and Guji Zones, Southern Ethiopia. Journal of Plant Pathology and Microbiology, 6: 16.

Mouen Bedimo, J.A., Bieysse, D., Nyassé, S., Nottéghem, J.L. and Cilas, C., 2010. Role of rainfall in the development of coffee berry disease in Coffea arabica caused by Colletotrichum kahawae, in Cameroon. Plant pathology, 59 :324-329.

Mulatu, A., 2012. Characterization and Testing of Antifungal Extracts from Trichoderma isolates against Fusarium xylarioides, the Causative agent of Coffee Wilt disease, pp. 1-70.

Negash, T. and Abate, S., 2000. August. Status of CBD in SNNP. In proceedings of the workshop on control of coffee berry Disease (CBD) in Ethiopia, pp. 18-28.

Nguyen Y., G. R. Tombeng Noumbo, E. Keute Kajdoum and C. G. Nchongboh, 2017. Antifungal Activities of Plant E, extracts against coffee berry disease caused by Colletotrichum kahawae L, 4: 60-66.

Omondi, 1998. Genetic diversity among isolates of Colletotrichum kahawae causing coffee berry disease and their interactions with varieties and breeding populations of Arabica coffee (Doctoral dissertation), pp. 1-138.

Owaka, M., 2011. Characterization of the genetic diversity and pathogenicity of Colletotrichum kahawae, using Random Amplified Polymorphic DNA (RAPD) analysis (doctoral dissertation school of pure and applied Science Kenyatta University, 7:225-263

Petty, J. Seaman, J. Majid, N. and Grootenhuis, F. 2004. Coffee and House hold povery: a study of coffee and household two district of Ethiopia. Save the children UK and DFID. Prihastuti, H., CAI, L., Chen, H., McKenzie, E.H.C. and Hyde, K.D., 2009. Characterization of Colletotrichum species associated with coffee berries in northern Thailand. Fungal Diversity, 39:89-109.Rakotoniriana, E.F., Scauflaire, J., Rabemanantsoa, C., Urveg-Ratsimamanga, S., Corbusier, A.M., Quetin-Leclercq, J., Declerck, S. and Munaut, F., 2013. Colletotrichum gigasporum sp. Nov., a new species of Colletotrichum producing long straight conidia. Mycological Progress, 12:403-412.

Rayners, R.W., 1970. A Mycological Color Chart: In Common Wealth Mycological Institute, Kew, Surrey, UK, pp. 20.

Robinson, R.A., 1976. Plant pathosystem. In Plant Pathosystem Springer, Berlin, Heidelberg, pp. 15-31.

Rodrigues, Jr., C.J., Várzea, V.M.P., Hindorf, H. and Medeiros, E.F., 1991. Strains of Colletotrichum coffeanum Noack causing coffee berry disease in Angola and Malawi with characteristics different to the Kenya strain. Journal of Phytopathology, 131: 205-209.

Rodriguez, G.A.A., 2016. Mode of action of Phialomyces macrospores as a biocontrol agent in coffee infected with Colletotrichum spp., pp. 1-55.

Saikia, R., Singh, T., Kumar, R., Srivastava, J., Srivastava, A.K., Singh, K. and Arora, D.K., 2003. Role of salicylic acid in systemic resistance induced by Pseudomonas fluorescens against Fusarium oxysporum f. sp. Ciceri in Chickpea. Microbiological Research, 158: 203-213.

Serani, S., Taligoola, H.K. and Hakiza, G.J., 2007. An investigation into Fusarium spp. associated with coffee and banana plants as potential pathogens of Robusta coffee. African journal of ecology, 45: 91-95.

Sillero, J.C., Rojas-Molina, M.M., Ávila, C.M. and Rubiales, D., 2012. Induction of systemic acquired resistance against rust, ascochyta blight and broomrape in faba bean by exogenous application of salicylic acid and benzothiadiazide. Crop Protection, 34: 65-69.

Silva, D.D., Crous, P.W., Ades, P.K., Hyde, K.D. and Taylor, P.W., 2017. Life styles of Colletotrichum species and implications for plant biosecurity. Fungal Biology Reviews, 31: 155-168

Silva, D.N.P.R., 2010. Analysis of the neutral and adaptive genetic variation of Colletotrichum kahawae and its relationship with the C. gloesporioides complex (Doctoral dissertation), pp.1-88.

Silva, M.D.C., Várzea, V., Guerra-Guimarães, L., Azinheira, H.G., Fernandez, D., Petitot, A.S., Bertrand, B., Lashermes, P. and Nicole, M., 2006. Coffee resistance to the main diseases: leaf rust and coffee berry disease. Brazilian Journal of Plant Physiology, 18:119-147.

Tadesse, G., Zavaleta, E., Shennan, C. and Fitzsimons, M., 2014. Local ecosystem service use and assessment vary with socio-ecological conditions: A case of native coffee-forests in southwestern Ethiopia. Human Ecology, 42:873-883.

Teferi, D. and Ayano A., 2017. Assessment of commercially grown coffee types for their tolerance to bacterial blight of coffee (BBC) at Sidama and Gedeo Zones, Southern Ethiopia. 6: 0.001-0.005

Teferi, D. and Belachew K., 2018. A review of coffee diseases research in Ethiopia. International Journal of Agriculture and Biosciences, 7: 65-70.

Temesgen, A. and Tufa. A., 2017. Analysis of Coffee Farm Productivity in Darolabu District, West Hararghe Zone, Ethiopia, 2: 158-161.

Temesgen, F. And Getachew, B., 2016. Analysis of technical efficiency of coffee production on small holder 
farmers in case of Sasiga \& Limu Districts of East Wollega Zone, pp, 1-36.

USDA (United states Department of Agriculture), 2018. Coffee world markets and trade foreign agricultural service in USA, pp.1-9.

Vaast P, Bertrand B, Perriot JJ, Guyot B, Genard M. 2006. Fruit thinning and shade improve bean characteristics and beverage quality of coffee (Coffea arabica L.) under optimal conditions. Journal of Science and Food Agriculture, 86:197-204

Van der Graff, 1981. Selection for Arabica coffee types resistant to coffee berry disease in Ethiopia. Mededelingen land Bouwhoge School, Wageningen, and Nederland. Pp. 110.

Van Der Graff, N.A., 1982. Resistance to coffee berry disease in Ethiopia the CBD programme from 1972 to 1979. Regional Workshop of Coffee Berry Disease, 1. Addis Ababa (Ethiopia) 19-23 July, 1982.

Van der Vossen, H., Bertrand, B. and Charrier, A., 2015. Next generation variety development for sustainable production of Arabica coffee (Coffea arabica L.): a review. Euphytica, 204: 243-256.

Van der Vossen, H.A.M. and Walyaro, D.J., 2009. Additional evidence for oligo genic inheritance of durable host resistance to coffee berry disease (Colletotrichum kahawae) in arabica coffee (Coffea arabica L.). Euphytica, 165: 105.

Vieira, A., Diniz, I., Loureiro, A., Pereira, A.P., Silva, M.C., Várzea, V. and Batista, D., 2018.Aggressiveness profiling of the coffee pathogen Colletotrichum kahawae. Journal of Plant Pathology, pp.1-32

Waller, J.M., 2007. Coffee Pests, Diseases and Their Management [electronic Resource]. CABI.

Waller, J.M., Bridge, P.D., Black, R. and Hakiza, G., 1993. Characterization of the coffee berry disease pathogen, Colletotrichum kahawae sp. Nov. Mycological Research, 97: 989-994. Waller, J.W., M. Bigger sand R.J. hillocks, 2007. Coffee pests, disease and their managements, pp. 211-215.

Weir, B.S., Johnston, P.R. and Dam, U., 2012. Colletotrichum gloesporioides species complex. Studies in mycology, 73:115-180.

Workafes, W., Kassu K. 2000. Coffee production systems in Ethiopia. In: Proceedings of the workshop on control of coffee berry disease in Ethiopia; 1999 Aug 13-15, Addis Ababa; p. 99-107.

Yadessa, G., 2014. Genetic Diversity, Pollination Ecology and Organoleptic characteristics of Coffea arabica L. in Ethiopian moist forests of different management Intensity. (Doctoral dissertation in the degree of Doctor Biology), pp. 1-200

Zenebe W., 2019. Assessment of coffee berry disease, characterization of colletotrichum kahawae isolates and evaluation of resistance in Coffea arabica collections from Gidame, western Ethiopia (doctoral dissertation, Jimma University).

Zeru, A., 2006. Diversity of Arabica coffee populations in Afromontane rainforests of Ethiopia in relation to Colletotrichum kahawae and Gibberella xylarioides, pp.1-68.

Zeru, A., Asefa F, Adugna G, Hindorf H., 2009. Occurrence of fungal diseases of Coffea arabica. In montane rainforests of Ethiopia. Journal of Application Botany and Food Quality. 28: 148-151.

Zeru, A., Assefa, F., Adugna, G. and Hindorf, H., 2012. Occurrence of fungal diseases of Coffea arabica L. in montane rain forests of Ethiopia. Journal of Applied Botany and Food Quality, 82: 148-151. 